\title{
LUNATICS AND IDIOTS: MENTAL DISABILITY, THE COMMUNITY, AND THE POOR LAW IN NORTH-EAST ENGLAND, 1600-1800
}

by

\section{PETER RUSHTON*}

Despite recent advances in the history of madness, we still know little of the mad themselves. This "silence at the centre" of the subject might be due to over-reliance on printed sources or institutional records (especially of famous institutions such as Bethlem or the Retreat), both of which may be unrepresentative. ${ }^{1}$ More fairly, the absence is probably due to the acute difficulties inherent in any attempt to search behind the published debates and individual cases for the social contexts that produced the mentally afflicted. Even for the nineteenth century, it has been admitted that the key processes by which the mentally abnormal, particularly pauper lunatics, were discovered, labelled, and sent to workhouses and asylums remain obscure. The detailed institutional records have been described as "abundant but ultimately frustrating" evidence. ${ }^{2}$ Yet the project of taking the study out of the institutions into a local social context is of crucial importance. The mentally abnormal were routinely mentioned in a wide variety of records in the early modern period, mostly as part of the organization of charity or poor relief, suggesting that this was the first era of widespread public attention to the problems they posed. These sources may unintentionally reveal the general concepts of mental disability that shaped the processes of social and official classification and response. The questions that require examination are why local authorities became concerned with the mentally disabled, and how they reacted. It is argued here that people such as overseers and magistrates were experienced, if not enthusiastic, in dealing with cases of mental disability. Secondly, it is the firm impression that they reacted to the problems in a coherent and consistent manner within the structure of limited resources, a concern for public order, and a division of welfare responsibilities between the family and the community. Whatever the solution adopted, it marked a shift from the predominantly familial system that dominated the medieval period, although there are some signs among the wills of the propertied that private provision was still not uncommon. ${ }^{3}$

*Peter Rushton, PhD, Senior Lecturer in Sociology, Department of Social Sciences, Sunderland Polytechnic, Sunderland SR2 7DX

${ }^{1}$ R. Porter, “'The Hunger of Imagination”: approaching Samuel Johnson's melancholy', in W. F. Bynum, R. Porter, and M. Shepherd (editors), The anatomy of madness: essays in the history of psychiatry. Vol. 1: People and ideas, London, Tavistock, 1985, p. 63.

2 J.K. Walton, 'Casting out and bringing back in Victorian England: pauper lunatics, 1840-70', in ibid; Vol. 2: Institutions and society, p. 143. See the collection of historical memoirs edited by Dale Peterson, $A$ mad people's history of madness, Pittsburgh, University of Pittsburgh Press, 1982.

${ }^{3}$ I owe this point to Mrs J. L. Drury, of the Department of Palaeography and Diplomatic, Durham, who 


\section{Lunatics and idiots}

This study focuses on the available records from the north-east of England, the two counties of Durham and Northumberland, whose regional centre was (and is) Newcastle upon Tyne, though some of the published records from the North Riding of Yorkshire will be used by way of further comparison. This large, sparsely populated region, bounded by the North Sea to the east and the Pennine Hills to the west, contained a considerable variety of local economies and communities. From leadmining and pastoral farming in the hills to coalmining, seafaring, and arable farming in the coastal plain, the pattern is diverse. After the end of the terrible border raids and famines of the Elizabethan period, the region developed in a consistent way, with fast-growing lowland towns and villages drawing population from the remoter uplands, especially in Northumberland where no leadmining occurred to offset the problems of the small hill-farmers. ${ }^{4}$ This pattern is reflected in the way that adequate parish poor law and charity records survive to provide data on the mentally disabled. It was the populous lowland parishes facing increasing problems of vagrancy and poverty that kept the best records; significantly, the poor law accounts became more detailed and complete in the eighteenth century as things grew worse. Thus, while ordinary parish registers were kept efficiently throughout the region from the sixteenth century, the essential poor law material is unevenly spread, both temporally and geographically. The quarter sessions, by contrast, which were the supervisory "capstone" of the poor law system, seem to have drawn cases from a wider area, though only Durham has records from the early seventeenth century. Oddly, some of the scantiest personal references come from Newcastle, which throughout the period was the pioneer of new institutional and professional treatment. New "hospitals" were founded there in the late-seventeenth and early-eighteenth centuries with public and private funds. After the foundation of a small private asylum in the seventeenth century, the city became the regional centre for medicine, with its infirmary (opened in 1752) and two asylums (founded in the 1760s). Yet we know little of its poor law system. $^{5}$

What follows is based on the cases of more than a hundred individuals, scattered through quarter session petitions and orders, institutional records of "hospitals" and infirmaries, and overseers' or churchwardens' records of twenty parishes. Whether this region is typical must await further work, for there is only one comparable study of the mentally disabled and the poor law, and this was based only on quarter sessions

pointed out the provisions for lunatics in local seventeenth-century wills. For the medieval period, see Elaine Clarke, 'Some aspects of social security in medieval England', J. Fam. Hist., 1982, 307-320.

${ }^{4}$ S. J. Watts and Susan J. Watts, From Border to Middle Shire: Northumberland 1586-1625, Leicester University Press, 1975, describe the chaos and late development of the poor law in the region (p. 202). For the best outline of economic development and demographic patterns, see P. Brassley, The agricultural economy of Northumberland and Durham in the period 1640-1750, New York, Garland Publishing, 1985 (originally an Oxford B.Litt. thesis, 1974).

${ }^{5}$ Parry-Jones makes Newcastle one of his case studies: see W.Ll.Parry-Jones, The trade in lunacy: a study of private madhouses in England in the eighteenth and nineteenth centuries, London, Routledge \& Kegan Paul, 1972, pp. 61ff. The poor law system in Newcastle in the seventeenth century seems to have been run by aldermen in their own parishes, with the odd result that we have no detailed parish or town account books. Just as the town was not necessarily the key community unit in Newcastle, so in some Northumberland parishes community conflicts led to the break-up of the parish into self-sufficient poor law wards: the subjective community, as so often, was not equivalent to the administrative unit. 
records. ${ }^{6}$ Almost certainly, the voices of the mentally afflicted will be muted, but in analysing the ways in which they were defined and brought to public notice we may understand something of their experiences. For these reasons the conclusions must necessarily be tentative.

\section{CONCEPTS AND CLASSIFICATIONS}

To both Whig and revisionist historians the lack of a clear set of categories is strongly associated with indiscriminate incarceration and brutal treatment. Without a clearly defined status, it is alleged, the mentally abnormal were regarded by the authorities as merely part of the large class of the poor rather than as a special problem. ${ }^{7}$ Yet there is considerable medieval evidence of both legal and medical interest in the careful differentiation of the mentally odd, and it is clear that a sophisticated literature existed on the subject by the early modern period. In addition, as MacDonald's fine study of Napier's notebooks show, it was possible for scrupulous attention to be paid to the understanding of mental disturbances in individual cases at the local level. ${ }^{8}$

The crucial conceptual distinction that arose from problems of property and title inheritance was between idiots and lunatics. This thirteenth-century legal doctrine distinguished those who were unfit to inherit because of supposedly innate mental incapacity from those who could be temporarily deprived of their inheritance while they were judged to be out of their minds. ${ }^{9}$ The courts seem to have developed a range of tests with which to explore and categorize individual cases, and, particularly in the fifteenth and sixteenth centuries, according to Neugebauer, the commonsense notions of competence in numeracy and social skills seem to have dominated the evaluation of awkward cases of idiocy in contexts such as the Court of Wards. ${ }^{10}$ That this medico-legal tradition remained strong in the two subsequent centuries is evinced in local poor law records, where the commonest terms for mental abnormality are "idiot" and "lunatic", suggesting a similar interest in the accurate identification of mental afflictions.

\footnotetext{
${ }^{6} \mathrm{~A}$. Fessler, 'The management of lunacy in seventeenth-century England. An investigation of quartersessions records', Proc. R. Soc. Med. (History Sect.), 1956, 49: 901-907. I am using the term "mentally disabled" to cover all kinds of abnormality or illness - see R. Neugebauer, 'Mental illness and government policy in sixteenth and seventeenth-century England', unpublished $\mathrm{PhD}$ thesis, Columbia University, 1976. The sample consists of 116 people, 83 of them lunatic, 33 idiot; 57 were found in quarter sessions records, the remainder in the records of poor law, charity and institutional relief. Of about thirty parishes which have decent records for the period, twenty produced cases of mental disablement.

${ }^{7}$ See, for example, Kathleen Jones, Lunacy, law and conscience, 1744-1845: the social history of the care of the insane, London, Routledge \& Kegan Paul, 1955, p. 8; and A. T. Scull, Museums of madness: the social organization of insanity in nineteenth-century England, Harmondsworth, Penguin Books, 1982, p. 22. But see V. Skultans, English madness-ideas on insanity, London, Routledge \& Kegan Paul, 1979, p. 55, for scepticism on this point.

8 J. Kroll, 'A reappraisal of psychiatry in the middle ages', Arch. gen. Psychiatry, 1973, 29:276-283; and M. MacDonald, Mystical Bedlam: madness, anxiety and healing in seventeenth-century England, Cambridge University Press, 1981.

${ }^{9}$ B. Clarke, Mental disorder in earlier Britain, Cardiff, University of Wales Press, 1975, p. 58. The distinction between illness and handicap seems to remain central to legal theory-see $\mathrm{N}$. Walker, Crime and punishment in Britain, Edinburgh University Press, 1965, ch. 13.

${ }^{10} R$. Neugebauer, 'Treatment of the mentally ill in medieval and early modern England: a reappraisal', $J$. Hist. behav. Sci., 1978, 14: 167; and idem, op. cit., note 6 above.
} 


\section{Lunatics and idiots}

Most records reveal little of the process through which individuals were detected and labelled, merely indicating the policies adopted after definitions had been agreed. But we can examine the range of terms used and, where a plea for help is being made, the kinds of arguments adduced in justification. It is apparent that while there was a variety of descriptions for idiocy, both among their kin and local officials, there was generally little contention over what they indicated. In the case notes, direct labels were sometimes used-“idiot", "fool", or "not compos mentis", but there was a general reliance, particularly by relatives, on the euphemistic "innocent" (such as "she hath an innocent son"). ${ }^{11}$ As in medieval times, these people were seen as incurably and naturally damaged, and the evidence cited was always concerned with their inability to perform everyday tasks. They could not count to twenty, name their parents or neighbours, clothe themselves, or go out unaided. ${ }^{12}$ Only one idiot was regarded by his community as dangerous, which may indicate that this affliction was not generally considered a threat to social peace.

Lunacy seems to have been the more problematical definition. Here, too, there was a range of terms, from the simple designations "madman/woman" or "lunatic", "disordered in the senses" or "distracted", to the rare "melancholy", "insane", or "crazy". In this, the north-east of England seems to have shared the basic variety of descriptions used elsewhere in the seventeenth and eighteenth centuries. ${ }^{13}$ However, lunacy was difficult to define, for a number of reasons. First, the social structure of the defining process differed from that in cases of idiocy, because much more attention was paid to the observations and anxieties of neighbours and the wider community. Magistrates were responsive to fear of violence or arson, and the public's accounts of the personal history of madness were often useful evidence; later in the period, medical experts would be called in to corroborate the popular diagnosis. Thus danger (to self or others) and public opinion were key factors in judging the seriousness of insanity. Second, the nature of lunacy was considered more complex than idiocy, as a temporary condition that eluded final definition. So all descriptions of victims were provisional, and often included hopeful wishes for recovery ("until such times as it shall please God to restore him to his right senses", the JPs said of an unfortunate North Riding vicar in 1697). ${ }^{14}$ This naturally had implications for any arrangements made for the care of a lunatic, especially if it involved incarceration or the transfer of property to relatives. The local authorities had to be prepared to reverse their decision, and face their public in doing so.

A final reason for the uncertainty in defining lunacy lies in the fact that it was a term used to sum up the changes in a person's character, referring to an accumulation of behavioural signs rather than any particular action. Thus almost any single item taken as evidence of dangerous insanity stands comparison with offences committed by

11 (N)QSB, 17, f.17 (1702). All manuscript sources are in the three CROs unless otherwise cited, Northumberland (N), County Durham (CD), and Tyne and Wear Archives Department (TW). Many thanks are due to the patient staff of these offices. In quotation, the spelling has been modernized.

12 Ibid., and (N)QSB, 34, f.18 (1711), (N)QSB, 53, f.57 (1720).

${ }^{13}$ See Fessler, op. cit., note 6 above.

${ }^{14}$ Rev. J. C. Atkinson, (editor), Quarter Sessions Records, vol. 7, North Riding Record Society, 1889, pp. 126-127, 160 (1692 and 1697). There are twenty-seven cases of lunacy and idiocy in the nine volumes of this series. 


\section{Peter Rushton}

people considered (or prosecuted) as criminals. As modern criminology, especially labelling theory, might lead us to expect, it was not the act but the actor that indicated madness: a threat to burn neighbours' houses or kill them was not sufficient by itself to justify the label "lunatic". Identification therefore was to some extent tautological: deviant behaviour only indicated madness if, in fact, the perpetrator was mad ("one mad action is not enough to prove a man mad", went an eighteenth-century proverb). The decisive process was probably conducted by friends and relatives rather than local officials, as happened in a Durham custody case in 1620 when the guardian of a young girl was reported to have gone mad. Two of his close friends visited him (one to spend a night in the same bed), to observe his "mad raging fits", raving words, and other odd behaviour. They concluded that if he continued showing such "light signs" he would be unfit to govern himself let alone anyone else. Thus those who had known him when sane were the crucial judges of his madness. ${ }^{15}$

\section{THE OFFICIAL DISCOVERY OF THE PROBLEMS}

As individuals were transformed from a private burden into a public problem, this idiot/lunatic dichotomy formed the basis of official reactions, with the exception of a man in 1770 who, disordered in his senses, was confusingly termed an "idiot lunatic". ${ }^{16}$ It is important to stress that no attempt will be made here to reclassify the behavioural characteristics of these individuals in our own terms (a difficult task, given the culturally-specific nature of the evidence, even where the modern authors are medically qualified). ${ }^{17}$ The aim is to examine the organized response to individual cases in order to discern the way that responsibility was divided between family and public care, between home and institution. In this sense, this is a case-study of the relationships between the family and the state (or rather, the local state, if that is the right term for the collection of local authorities) in early modern England.

The first question that arises is what kind of problem was brought to the different bodies and who initiated the process. As Fessler suggested, by far the most detailed source is the petitions before the quarter sessions, as only in circumstances of pleading for help did people explain in detail the nature of the problem they faced. We can only surmise that these cases do not differ substantially from those found in other, more uninformative, sources such as parish and charity records, which, by contrast, deal rather more clearly with the solutions adopted. Many cases, of course, arose because of disputes between parishes over the settlements of mentally disabled paupers, which may leave us in the dark about their exact origins. ${ }^{18}$

\footnotetext{
${ }^{15}$ MacDonald, op. cit., note 8 above, p. 165. Department of Palaeography and Diplomatic, Durham, DR.V, 11, f.56v, Browne against Proctor (my thanks to Mrs J. L. Drury for tracing the subsequent development of this case). Fear of arson seems to have been widespread, but the three lunatics associated with it are exceeded by the number of apparently "normal" citizens (four in Northumberland alone, all earlyeighteenth century). For classic deviance theory, see E. Rubington and M. S. Weinberg (editors), Deviance: the interactionist perspective, London and Toronto, Macmillan, 1968.

${ }^{16}(\mathrm{CD}) \mathrm{Q} / \mathrm{S} / \mathrm{OB}, 13$, p. 281.

${ }^{17}$ For an unsatisfactory exercise of thissort, see J. G. Howells and N. L. Osborn, 'The incidence of emotional disorder in a seventeenth-century medical practice', Med. Hist., 1970, 14: 19-28.

${ }^{18}$ Fessler, op. cit., note 6 above, p. 902.
} 


\section{Lunatics and idiots}

With regard to idiots, the cases were nearly always brought by relatives faced by financial difficulties. Families were in desperate poverty, especially if they had had to care for someone for many years. James Twizell was looked after for forty years by his sister and brother-in-law, his only relatives who, in theory, had no legal obligation to care for him. He was "born a fool which is the cause of his poverty". ${ }^{19}$ Other relatives could be similarly burdened by unavoidable responsibilities. A Northumberland widow in 1711 cared for two girls: "that's my grandchildren and the youngest is about thirty years of age and neither of them can tell to twenty .... I am burthened something with them because they are not capable of service", she said. ${ }^{20}$ These cases of long-term poverty are common in all areas, though Northumberland was unusually rich in cases of idiocy.

The only instance of idiocy causing anxieties about public order occurred in Northumberland in 1702, when Margaret Williamson of Allendale petitioned concerning her "innocent" son, a twelve-year-old "incapable of knowing any by name or face yea his own mother". He was described as "unruly", and so "past Government that without a continual eye had unto him she is in daily fear of some ill to be done by him either to her, himself or to some others". The neighbours were endeavouring to compel her to "attend him with watchful eye in the house". She had a second child by a second (disabled) husband, and requested financial aid to "keep her in the house with him which will be the safety of the neighbourhood". 21

Other problems arose when an individual solution to the care of the victim fell down, or because a responsible person defaulted. For example, when an arrangement to "table" someone with another family for a given fee was threatened by non-payment, the idiot would be returned. So, when "Carlson, an Infant" was tabled with William Ironside by William Sutton who promised to pay the fourteen pounds belonging to her for her "diet", it seemed a reasonable agreement. But Sutton failed to pay up, and Ironside sent the child back to her "home". In other instances, a crisis was precipitated by the death of the caretaker, which left the parish seeking an alternative. ${ }^{22}$

In other cases, it was not so much the idiot as the consequences of his family's policy that created difficulties. One Northumberland woman was in dire poverty because she had been persuaded to marry a "simple man", the son of the house where she was a servant, because his parents had grown too old to "manage their concerns as they had formerly done". Unfortunately, she suffered a crippling accident and was ejected from the house, with even her servant's wages left unpaid. She was forced to return to her equally poor mother. ${ }^{23}$

Thus most of the problems of idiocy stemmed from family poverty and the failure to arrange an effective system of domestic care. Most of the cases were brought by the caretakers, and consequently bear a strong resemblance to other poor law cases of families beset by sickness or disability. In general, idiocy was an accepted cause of poverty, both for the individual and his family, and is often cited as a self-explanatory

${ }^{19}$ (N)QSB, 9, f.15 (1697).

20 (N)QSB, 34, f. 18.

21 (N)QSB, 17, f.17.

22 (CD)Q/S/OB, 3 \& 5, p. 249 (1665); (N)QSO, 7 p. 255 (1735).

23 (N)QSB, 11, f.53 (1699). 
note in lists of households too poor to pay rates or people deserving of special charity. ${ }^{24}$ They stand in interesting contrast to those cases involving lunacy, which seem to have arisen from a wider, less kin-based group of locals, perhaps reflecting a more communal involvement in the problem. Partly, this was because lunatics were adults, whereas about half of the idiots for whom we have evidence of age were young dependants. Consequently, lunatics were far less likely to have relatives available to care for them. But the problems they posed seem to have more diverse. Like idiots, lunatics are found receiving aid from a wide range of parish and other local authorities.

The obvious reason for community responsibility was that some lunatics were dangerous. It is a much-repeated image of the pre-asylum period that the majority of lunatics dealt with by the public authorities were a problem of vagrancy or violent danger to social order. Certainly, as MacDonald has suggested, the terms "mad" or "lunatic" or "distracted" were definitions that inherently indicated potential if not actual violence. ${ }^{25}$ So it is commonly asserted that while the mentally disabled posed no particular social problem in the early modern period, public measures were taken when disorder could not be contained within the confines of the family unit. ${ }^{26}$ In fact, violence of threats of it were quite rare in the north-east cases, being mentioned in less than a tenth of the total, though in a fifth of those dealt with by the magistrates. The latter, quarter sessions cases, were clearly referred to a higher authority because neighbours or parish officers felt that they could not cope with the problem at the local level. This suggests that the majority of the ordinary parish cases were none too severe or threatening. ${ }^{27}$ Typical examples were those of Mary Mitchell in Broome, County Durham, who in 1691 was simply described as "lunatic and very dangerous to the neighbourhood", while the other dangerous woman in the records, Dorothy Turpin, had required four or six people to attend her in 1665 when she had "fallen into a sad distraction of mind", and was so "ragious" that she had threatened to burn some house in the town of Carnforth. ${ }^{28}$ Threats to kill people are mentioned in cases of male lunatics: in one case, in 1758 , there was a general anxiety that killing might occur, but in another, in 1762 , threats were alleged to have been made to kill "several persons". ${ }^{29}$ Other lunatics clearly had a history of unruly behaviour and were beyond local control, one being described as having committed "several outrageous acts and put the inhabitants in fear of their lives and of having their houses burnt and their goods and cattle destroyed". 30

\footnotetext{
${ }^{24}$ Stockton, 1722, (CD)EP/Sto, 42, p. 5; Corbridge, 1714, John Cooke's bequest, (N)EP./57/25 (unpaginated: Easter 1714).

${ }^{25}$ M. MacDonald, 'Popular beliefs about mental disorder in early modern England', in W. Eckart and J. Geyer-Kordesch (editors), Heilberufe und Kranke im 17. und 18. Jahrhundert die Quellen-und Forschungssituation, Münster, Münstersche Beiträge zur Geschichte und Theorie der Medizin, 1982, pp. 148-173. Other deviants were also feared because of potential rather than actual danger, such as vagrants: see A. L. Beier, 'The social problems of an Elizabethan country town: Warwick, 1580-90', in P. Clark (editor), Country towns in pre-industrial England, Leicester University Press, 1981, p. 58.

${ }^{26}$ See A. T. Scull, 'From madness to mental illness: medical men as moral entrepreneurs', Arch. Europ. Sociol., 1975, 16: 218-151, p. 222.

${ }^{27}$ All seven cases of actual or threatened danger occur among the thirty-five quarter session lunatics; parish records are silent about public anxiety (see below for security measures).

${ }_{28}$ (CD)Q/S/OB, 3 \& 5, p. 241 (1665), and (CD)Q/S/OB, 7, p. 268 (1691).

${ }^{29}$ (CD)Q/S/OB, 11, p. 310 (1758), and (N)QSO, 9, pp. 468, 476 (1762).

${ }^{30}(\mathrm{~N}) \mathrm{QSO}, 4, \mathrm{ff} .382-382 \mathrm{v}(=\mathrm{pp} .482-3)(1710)$; see note 15 above - arson seems to have exercised a peculiar fear on the public mind.
} 


\section{Lunatics and idiots}

The wandering lunatic was also found, though again in small numbers. One, in 1761, appeared before the Northumberland magistrates, "a person who calls herself by the name of Jane and says she comes from the Highlands of Scotland". She seemed to them "so far disordered in her senses that it is dangerous to permit her to go abroad". Similarly in Durham the following year, a woman called Christian Goode, "destitute of clothes, and almost naked and in a loathsome condition", was discovered to be "disordered in her senses and incapable of giving any account of her Settlement". 31 Here the old problems of vagrancy and lunacy coincided in a way that meant that care would have to be a county rather than a parish responsibility. ${ }^{32}$

Most cases, however, may have arisen out of the need for familial or communal care of lunatics who could not look after themselves. Here lunatics came to the authorities' attention for much the same reason as idiots, through the poverty or neglect of their caretakers. Thus Mary Collingwood petitioned in 1699 for help from the Northumberland magistrates for her daughter, a cripple whose five-and-a-half-year melancholy was now gone, and her "reason restored", but who was still in great want. Another widow petitioned in 1706 because her son-in-law, a seaman in the navy, sent no money home, where her daughter had become a lunatic, forcing her to look after an infant grandchild. Other cases confirm that familial poverty caused by the presence of a lunatic was frequently the spur to bringing cases to the public arena. ${ }^{33}$

As in cases of idiocy, arrangements for domestic care of lunatics sometimes collapsed, compelling the magistrates to intervene. Mary Peacocke had been sent inland from Sunderland to be cared for by William Laborne of Bishop Middleham, who was to be paid twelve pounds yearly by her stepfather John Jopling. In 1674, the money ceased, even though Jopling had "received a considerable fortune with his wife", funds left by Mary's father specifically for her care. Mary was returned to her stepfather (a "gentleman") in Sunderland. ${ }^{34}$

These petitions demonstrate the diversity of causes that provoked public and official action. Together with the less detailed records at the parish level, they also show that there could be great variety of solutions.

\section{RESPONSES AND OPTIONS}

An outline of the statistical evidence indicates simply enough the way that the conceptual and practical differences between idiots and lunatics shaped local policies. Idiocy was overwhelmingly a domestic problem: all those whose residence is given were with kin or in domestic care. There are no hints that custodial confinement for idiots was ever considered by parish officers or magistrates-not even in the one case discussed earlier where disorder was a potential threat. This may reflect the fact (see above) that many were young, for more than half of those whose age is indicated were dependants. On the other hand, perhaps we should be surprised by the number of adults, a possible sign that there was no familial policy of negligence or infanticide.

31 (N)QSO, 9, p. 423 (1761), and (CD)Q/S/OB, 12, p. 151 (1762).

32 See A. L. Beier, Masterless men: the vagrancy problem in England, 1560-1640, London, Methuen, 1985, pp. 115-117.

${ }_{33}$ (N)QSB, 12, f.13 and (N)QSB, 13, ff.65 and 73 (1699-1700); (N)QSB, 24, f.27 (1706).

${ }^{34}$ (CD)Q/S/OB, 6, q.191. 


\section{Peter Rushton}

There is one oddity in the general figures for idiots: males outnumbered females by $3: 1$, which is in contrast to the more or less equal sexual distribution of lunatics. One clear exception therefore existed to the alleged increased use of confinement to "police" the early modern population, for it did not extend to idiots who, whether adults or children, were hidden away at home, where the local poor law authorities were determined to keep them. The overall official aim was to support the family if necessary, but not to replace it: to judge from the tone of many petitions, this matched the general desire of relatives to provide a decent home for their unfortunate kin. ${ }^{35}$

Lunatics, by contrast, were subject to a wide range of constraints, both domestic and institutional, and this confirms the basic idea of earlier theorists (such as Foucault) that lunacy, even when not actually dangerous, was seen to require social control for the public good. ${ }^{36}$ Of eighty-three cases, twenty-four were in the gaols or houses of correction, while an additional twenty-five were under some degree of restraint, ranging from domestic confinement to the workhouse or asylum. Whatever its exact form, restraint dominated the policy towards the insane. So all those discussed earlier who posed a threat of danger were confined in some way or another, but this was equally likely to occur with a large number when no specific alarm had been raised (or recorded). Yet while this looks like evidence of a standard policy for incarcerating the unreasonable, till they became "conformable", it is apparent from a careful scrutiny both of the variety of individual examples, and their case histories, that the local authorities tended to proceed cautiously, adopting a number of different strategies as the problems worsened or diminished. ${ }^{37}$

Certain cases indicate that on occasion the authorities felt sufficiently confident to treat lunatics as typically indigent and sick poor, either in their own or other people's homes. These were those whom Fessler describes as the "safe" lunatics. ${ }^{38}$ They emerge in many records rather by accident. In a Sunderland survey of 1720 , for example, they are discovered among the families too poor to pay rates. Of about 550 households listed, five were affected by lunacy: in two cases the victim was the male householder, in three the wife. Perhaps because Sunderland was a new parish, with no institutions (not even a workhouse), it was felt that these unfortunates were better left at home. But even where a workhouse was in operation, it may not have been considered suitable for lunatics. Berwick, for example, undertook a more restrictive policy for out-relief in the 1750 s, denying aid to any outside the workhouse who were not bedridden or in "extreme adversity". Among those who continued to receive help "out of the house", though, were one idiot and two lunatics. ${ }^{39}$ Similarly, while giving out weekly allowances and licences to beg in 1658-9, the parish of Eglingham (Northumberland) granted three pence weekly to Elinor Watson, a widow, "having a charge of children and distracted sometimes". ${ }^{40}$ This last case raises questions of how many of the insane

\footnotetext{
${ }^{35} \mathrm{C}$. Lis and $\mathrm{H}$. Soly, 'Policing the early modern proletariat, 1450-1850', in David Levine (editor), Proletarianization and family history, Orlando, Florida; Academic Press, 1984, pp. 179-180.

${ }^{36}$ M. Foucault, Madness and civilization: a history of insanity in the age of reason, London, Tavistock, 1967.

${ }^{37}$ An early pauper in the Durham house of correction was to remain there till he became "conformable"; (CD)Q/S/OB, 1, p. 165 (1622).

${ }_{38}$ Fessler, op. cit., note 6 above, pp. 902-903.

39 (CD)EP/Su.HT., 7/1 (1720); (N)EP.38/57 (unpaginated, 17 May 1763).

40 (N)EP.156/35 (unpaginated, annual lists for 1658 and 1659).
} 
who are simply listed as recipients of relief, with no hint of custody or care by others, were left in virtual independence. Some are cited in lists that read like the cast of seventeenth-century dramas: "Chicken-a lunatic: $£ 1-5 s$ ", is all we know of one man who received money from the Holy Jesus Hospital (Newcastle) for eleven years from $1723 .{ }^{41}$

Some recipients were in lodgings, as exemplified by a Newcastle case in 1657 , when the Common Council made an ex gratia payment to "a poor distracted woman that dwells in Alan Gilpin's house" (presumably, like others given special payments, she was "known to" members of the council). But many of these domesticated lunatics were with kin, who, as mentioned earlier, might have acquired the family property to offset the costs of maintenance. In many cases the income from rents or other assets alone was reallocated, rather than the property itself, as can be seen from a North Riding case. A tenant was ordered to pay his rent to the person (probably a sister) who had looked after his landlady for six months when she was distracted. ${ }^{42}$ When the property itself was transferred, the magistrates could only make a temporary decree: "till the Chancellor make further order", they said in a Durham case of 1673, when two men acquired the control of their kinsman and his property, implying that the measure was subject to civil proceedings. ${ }^{43}$

In other instances, neighbours who had taken care of a mentally deranged person at the onset of their affliction were forced to apply for help. Mary Aydon of Morpeth looked after Mary Forster, a vicar's widow, for twenty weeks before applying: "your petitioner is a poor woman, and the said Mrs Forster being Melancholy, requires constant attendance. Your petitioner therefore humbly requests your Worships will please to commiserate her condition and order her ... removed to other lodgings". ${ }^{44}$ This kind of domiciliary arrangement, identical to that favoured as a solution to idiocy, seems to have been the first resort of communities faced with a case of lunacy. The initial aim seems to have been to maintain the domestic status quo. In many eighteenth-century cases, as a consequence, especially in the large parishes, there was a small army of people (both men and women) employed to "watch" the sick, including the mentally deranged. Thus Bishopwearmouth in 1747 paid one pound to two men for "attending Anthony Garford when distracted, one week", and similar efforts were made in other parishes. On occasion, these turned into a near-permanent arrangement: in 1762, a Barnard Castle couple, Thomas Appleby and his wife, were paid four shillings a week for looking after George Harrison for five weeks during his insanity. In other cases, the costs of the "watcher" or "watchers" were borne by relatives-by a son-in-law in one 1672 example. $^{45}$

${ }^{41}$ (TW) 595/49, pp. 51, 53, 64, 66, 71, etc. to 84. Deborah Cloughton, a Gateshead idiot, was on the parish books from 1780 to 1815; see Account of the Out-Poor of the Parish of Gateshead, Taken in March 1815 ..., Newcastle, J. Akenhead, 1815.

42 (TW)Calendar of the Common Council Book, 1650-1659, f.448; Atkinson, op. cit., note 14 above, vol. 7 , (1889), p. 91.

${ }_{43}$ (CD)Q/S/OB, 6, p. 150. See Jones, op. cit., note 7 above, for the legal framework of property transfers in the eighteenth century. There are no signs of this case in the records of the Durham Chancery (PRO).

44 (N)QSB, 46, f.43 (1717).

45 (CD)EP/Biw., 143 (unpaginated, 1747); (CD)EP/BC., 7/278 (unpaginated, 18 May 1762); (CD)Q/S/OB,6, p. 119. 
These domestic arrangements sometimes required a degree of security as well as welfare, for which most houses were scarcely equipped. Stockton, for example, paid for special locks for the houses of the insane- "to Richard Bentley, a Lock for Mad Joseph Barber 1s-0d". ${ }^{46}$ In other cases, the difficulty was resolved through confinement by village officials, as occurred in Houghton-le-Spring in 1754, when "the Mad Man" was held for two nights by the constable. ${ }^{47}$ When the lunacy persisted, and the communal responsibility was decided and unavoidable, some longer-term arrangements were needed. Here, the problem was to strike a balance between the (generally) cheaper policy of retaining the victim in domestic circumstances and the necessity to protect the community. A good example of this is the case of an undoubtedly dangerous lunatic, Richard Dobson of Heighington (County Durham), who, in 1758, was considered a threat to the lives of his neighbours. The overseers were ordered to "keep him safely locked up or secured in some secure place within the said County or in the House of Correction ..., and if necessary to chain him during the continuance of his lunacy, and no longer". However, his mother, Jane, petitioned to take care of him, promising to keep him safely locked up in her house, and, if necessary, to chain him there. ${ }^{48}$

Domesticity could thus be used to guarantee public safety, but if the family could not perform the task, the parish could employ a squad of inhabitants to do what was deemed necessary. In a long-running case the parish of Houghton-le-Spring undertook to care for Jane Ovington, a local woman, who was "out of her reason". Initially, in 1765 , she was confined to a stable for twelve weeks, which incurred expenses for her subsistence and straw for the stable; pay for two men to clean the stable and replace the straw, and for a third to shave her head; and the fees of the local doctor (whom the overseers regularly employed for treating paupers) for medicines and bleeding. Subsequently, she seems to have recovered, though she is listed repeatedly as a recipient of relief over the next decade, and also incurred expenses for medical treatment again, especially for purges: from this it might be inferred that she probably had relapses or, at least, became one of the local population of permanent paupers on the parish books. What is of great interest here is the determination of the local officials to keep this woman in local custody rather than send her to their workhouse or the house of correction. The reasons were probably financial, for any institution involved considerably increased expense for the parish. In Jane Ovington's case, the parish paid little more than the usual expenses of maintaining a pauper (just over a shilling a week), and that for only a few months, whereas from the mid-seventeenth century onwards the costs of incarceration in a house of correction could be two or three times that amount. In one extreme example in Northumberland in 1724, the cost was seven shillings a week. ${ }^{49}$ The Ovington case occurred just at the point when specialist medical treatment of the insane became available in Newcastle for the paupers of the region.

${ }^{46}$ (CD)EP/Sto., 43, pp. 357 and 392 (1752-3).

47 (CD)EP/Ho., 256 (unpaginated, 1753-4 accounts). Orders to arrest or apprehend a lunatic are quite common in the quarter sessions-see (CD)Q/S/OB, 1, p. 366 (1629) for the earliest example.

48 (CD)Q/S/OB, 11, p. 310.

49 (CD)EP/Ho., 256 (unpaginated, annual accounts 1765-6). She is found for many years receiving relief, in EP/Ho., 45, 1775-1800. (N) QSO, 6 pp. 353 and 362. 
This raises the question of another balancing calculation that local authorities had to undertake-not only between domestic as opposed to institutional confinement, but between different kinds of institution. The slow development of the public and semi-private asylum complicated an already complex picture. Just as it is difficult to understand why gaols or houses of correction were selected in the period before 1760, so the reasons for choosing the asylum rather than domestic or penal confinement in the rest of the eighteenth century remain obscure. As a means of analysing this complex process of choice, it is necessary to compare the pattern of institutionalization before the asylum with that which developed afterwards.

\section{INSTITUTIONALIZATION AND THE RISE OF THE ASYLUM}

I have tried to suggest that, on the whole, local authorities were cautious about using incarceration unless the danger from lunatics was so great as to render it unavoidable. When there was no apparent choice, one option was penal custody, for which houses of correction, those "mixed hospitals" as Francis Bacon called them, were favoured in three-quarters of the sentences. Exactly why gaols were chosen for the remaining few is unknown; it might have been a simple problem of shortage of space. ${ }^{50}$ The purpose of the confinement is usually left unstated, and in only one case is punishment stipulated. In 1664, the Durham quarter sessions ordered that Henry Welbourne of Bransburton was to be "committed to the house of correction to work for his living; or to be whipped, the court being of opinion the person is distracted" (the only reference to the whipping of the insane). ${ }^{51}$ In most other cases the mad were just confined, with no special instructions, though it seems likely that they received a differential amount of attention, judging from the number of repeated listings of expenditure (which are rarely found for normal inmates). Another factor may have been the suspicion that the lunatic was faking his condition, so, as in cases of questionable physical disablement, the confinement may have been intended to test the genuineness of the affliction. ${ }^{52}$ They would certainly have suffered with other inmates from the poor conditions that beset underfunded houses of correction and gaols. These problems were reported frequently to the magistrates nominally responsible, and later given eloquent testimony by John Howard, who noted the presence of lunatics in the gaols of the $1770 \mathrm{~s} .{ }^{53}$ Whatever the institution chosen, there are no signs before establishment of the asylums that authorities in the north-east ever considered special facilities for the insane. Unlike the city of Nottingham in the early seventeenth century, Newcastle never spent money on "cabins" for the mad and a permanent staff to watch over them. None of the old "hospitals" seems to have admitted lunatics in addition to respectable paupers. ${ }^{54}$

\footnotetext{
${ }^{50}$ Quoted in S. S. Tollit, 'The first house of correction for the county of Lancaster', Trans. Hist. Soc. Lancs. and Cheshire, 1953, 105: 71. In this sample, of twenty-four in custody five were in gaols rather than houses of correction.

${ }^{51}$ (CD)Q/S/OB, 3 \& 5, p. 211. Whipping of the insane became illegal in 1714 (12 Anne c.23), Parry-Jones, op. cit., note 5 above, p. 7.

${ }_{52}$ Fake disablement is found in Durham-(CD)Q/S/OB, 9, p. 191 (1738) but not fake madness.

53 John Howard, The state of the prisons, London, Dent, 1929, p. 199. For Durham, see R. E. G. Cranfield, 'Durham prisons in an age of change', Bull. Durham County Local Hist. Soc., 1981, 28: 16-54.

${ }_{54}$ Records of the Borough of Nottingham, Vol.5, 1625-1702, Nottingham, City Council, 1900, p. 184 (4 July 1637).
} 


\section{Peter Rushton}

Incarceration was not necessarily irrevocable. Eighteenth-century magistrates frequently ordered the release of the mentally disturbed when they thought it safe to do so, though as Fessler points out, it was a decision taken without medical assistance. ${ }^{55}$ For example, Ralph Bone, one of those who had threatened to kill several persons, was confined in the Northumberland house of correction in January 1762. By Easter, "it appearing to the court that he is now well and sane", and with a man expressing willingness to employ him and "take proper care of him", Bone was released. Similarly, a lunatic in gaol was released in 1748 when the court concluded that he appeared "to be very well and to have quite recovered his reason", having first entered a recognizance for his good behaviour. ${ }^{56}$

During the same period, however, it was common for lunatics to become near-permanent inmates. While a number of lunatics were confined for two or three years, Eleanor Murray was in the Northumberland house of correction for more than nine years following her entry in 1743. Of unknown settlement in the county, which meant that the expenses had to be met from county funds, she may have died in confinement. ${ }^{57}$ The mastership of this house of correction lay with a father and son for much of the middle period of the eighteenth century, and for more than thirty years they had continual involvement with the care of lunatics. There seem to have been fewer complaints and criticisms of the conditions in this institution at this time compared with the later seventeenth century, though the inhabitants of the gaol were constantly petitioning over their poverty and general treatment. So perhaps the Northumberland lunatics were not so "slovenly and sad" as their contemporaries in Bethlem. ${ }^{58}$

The rise of experts, physicians, and their asylums, however, added a further dimension to local responses to the problem of lunacy. Indeed, the gradually increasing use of medical expertise by local poor law officials is a striking phenomenon of the eighteenth century. A century before, only Newcastle seems to have employed a Town Physician for the benefit of the poor (as well as a plumber to deal with the sewerage system); certainly there was nothing as systematic as the medical aid available in Norwich, as Pelling describes it. ${ }^{59}$ But in the eighteenth century, it became increasingly common for all parishes, whether urban or rural, to pay for the services of a doctor as well as nurses and midwives. In addition, the custom of sending paupers and other parishioners to infirmaries became widespread. While evidently few physicians were bound by contracts like that in Newcastle, where in 1700 Robert Grey was "to be

\footnotetext{
${ }^{55}$ Fessler, op. cit., note 6 above, p. 902 . See Jones, op. cit., note 7 above, p. 30, on the implications of the 1744 Vagrancy Act for the release of the insane. The law assumed that madness was easily perceptible by laymen.

${ }_{56}(\mathrm{~N}) \mathrm{QSO}, 9$, pp. 468 and 476; (N)QSO, 8, p. 236; and (N)QSO, 10 p. 27 (1764).

57 (N)QSO, 7, pp. 354, 386 and 420 (1738-40); (N)QSO, 8, pp. 143 and 229 (1745-7); (N)QSO, 8, pp. 43 to 532 (1743-53).

${ }^{58}$ Quoted in M. Byrd, Visits to Bedlam: madness and literature in the eighteenth century, Columbia, S. Carolina, University of Columbia Press, 1974, p. 40. But see P. Allderidge, 'Bedlam: fact or fantasy?', in Bynum et al. (eds.), op. cit., note 1 above, vol. 2, pp. 17-33.

${ }^{59} \mathrm{See}$ (TW) Calendar of Common Council Book, 1645-50, f. 197; 1656-1722, f.160. Payments were made to doctors for the poor in the sixteenth century, but there does not seem to have been a permanent post - see (TW) Calendar of Chamberlain's Account Book, 1561-4, ff.136 and 159. For a contrast with Newcastle, see Margaret Pelling, 'Healing the sick poor: social policy and disability in Norwich, 1550-1640', Med. Hist., 1985, 29: 115-137.
} 
careful and diligent and observant in the care of the poor people who were sick and ... not to leave the town for more than a night or two without a licence from the town", they were increasingly in close co-operation with overseers and other poor law officials. ${ }^{60}$ Although physicians were employed from the 1730 s, parish records indicate that the infirmary became an important possibility only around 1760, contemporaneously with the asylums. Some of these decisions involved transporting patients over extraordinarily long distances: one patient, in 1773, was moved from Tweedmouth to Newcastle Infirmary, more than sixty miles, while another, in 1759, was sent from Whickham (on the Tyne) to the Edinburgh Infirmary, more than one hundred miles. However, much informal aid continued to be employed: a "doctress" in the City of Durham received payment for services from Houghton-le-Spring in 1780. Moreover, medical treatment continued to be indiscriminate, for parishes such as Whickham continued to employ a man to bleed their paupers in the workhouse (all sixty-eight of them, in 1760 , at three pence a head). ${ }^{61}$

The infirmaries probably drew in many who were mentally disabled or otherwise behaviourally odd. Certainly, as Woodward suggests, they admitted epileptics and hysterics, and evidence exists for this in the annual reports of infirmaries in Newcastle and Manchester in the 1750s. ${ }^{62}$ This continued to be the case in Newcastle, whose infirmary was deliberately designed to serve the three counties around it (Northumberland, County Durham, and Newcastle itself), and consequently drew patients from a wide area. As the surviving admission records (from the late 1770s) show, many hysterical or epileptic patients, and one melancholic, were referred there. The latter, sent from the north-Northumberland village of Doddington, had suffered for two years from the condition before her short stay in 1779. The hysterics, who had mostly suffered much longer before admission, tended to stay two or three months before being discharged, though , exceptionally, one remained for three years. ${ }^{63}$ The records show that these patients were usually referred to the hospital by local notables-vicars, landowners, and others, which might explain the absence of hysterics from parish records dealing only with the seriously sick poor. In this division between the infirmary and the asylum, we might see the institutional reflection of a dichotomy of mental patients into the acute and the chronic that has bedevilled psychiatric theory ever since. ${ }^{64}$ Perhaps it is more likely that it was a dichotomy based on the legalistic theory that saw conditions such as melancholia as only "partial insanity". This would

${ }^{60}$ (TW) Calendar of Common Council Book, 1656-1722, f.216v.

${ }^{61}$ (N)EP. 79/33, (unpaginated, 17 September 1773);(CD)EP/Whm., 19, pp. 48, 154 and 160; (CD)EP/Ho., 256, (unpaginated, 2 July 1780 ).

62 John Woodward, To do the sick no harm: a study of the British voluntary hospital system to 1875, London, Routledge \& Kegan Paul, 1974, p. 162.

${ }^{63}$ George Haliburton Hume, The history of Newcastle Infirmary, Newcastle, Andrew Reid, 1906, p. 11; (TW) 1212/1, (unpaginated, 16 September 1779).

${ }^{64}$ O.M. Marx, 'The case of the chronic patient seen from a historical perspective', in E. R. Wallace and L.C. Pressley (editors), Essays in the history of psychiatry: a tenth anniversary supplementary volume to the psychiatric forum, Columbia, S. Carolina, Wm. S. Hall Psychiatric Institute, 1980, pp. 22-29; Ilza Veith, Hysteria: the history of a disease, Chicago University Press, 1965. K. Doerner, Madmen and the bourgeoisie: $a$ social history of insanity and psychiatry, Oxford, Basil Blackwell, 1981, suggests (p. 63) that there is a class difference in patients with serious insanity and mild nervous diseases, the latter belonging to the curable middle classes. 
tend to favour grouping melancholic or hysterical patients with the epileptics in infirmaries where treatment was thought efficacious, while the incurable lunatics were locked up elsewhere. ${ }^{65}$

If the most serious cases of mental disability were considered appropriate for the asylum in the last third of the eighteenth century, it is important to note that this was not the only solution adopted. For one thing, idiocy continued to be a domestic matter, because none of the new generation of "mad doctors" or asylum managers offered a cure for congenital conditions. Consequently, few asylums, not even the exemplary Retreat in York, favoured the admission of idiots. ${ }^{66}$ For another, lunatics continued to be sent to workhouses, gaols, and houses of correction till the end of the century, often by the same parishes which were simultaneously sending some to the asylums. At least a third of those with a recorded location between 1760 and the end of the century were in penal custody, which suggests great continuity with the previous policies. So a contradiction is apparent, as parishes seem both eager to take up the opportunities offered by the new asylums and simultaneously determined to go on in some of the old ways. Variations between parishes meant that while one would favour local confinement (as in the case of Jane Ovington in 1765, above), another nearby would simply send a lunatic straight to the new asylum. In Durham, though the figures are small, the asylum seems to have achieved a near-monopoly after the 1770 s, though there was one case of workhouse confinement in 1793. But this policy was not without opposition, not least from the insane themselves. One petition in 1785 before the magistrates was brought by John Collins in the West Auckland asylum, appealing against his incarceration under the 1744 Act. After reading his statement and interviewing available witnesses, however, the JPs disallowed the appeal. ${ }^{67}$

In Northumberland, where late-eighteenth-century cases are rather more numerous, the picture is more varied. A parish like Tweedmouth adopted different strategies: in 1798 , domiciliary care was chosen for one lunatic who was later transferred to a nearby parish; in 1786 and 1798 two lunatics were sent to the "Lunatic Hospital" in Newcastle; and in 1799, the parish constable had to be paid especially to take food to one Prudence Hall who was in the gaol at Berwick (for fifteen days at least) ${ }^{68}$ Other parishes showed similar diversity, most probably on grounds of cost. Just as a house of correction inmate was twice as expensive for a parish as an ordinary pauper, so the asylum was twice as costly again: the weekly rate could rise to five or six shillings during the last third of the eighteenth century, when most paupers received between one and two shillings. Perhaps the best guide to how a parish might proceed at the end of the eighteenth century is provided by an unusually detailed case in Alnwick in 1798-9. A

\footnotetext{
${ }^{65}$ Stanley W. Jackson, 'Melancholia and partial insanity', J. Hist. behav. Sci., 1983, 19: 173-184. There is one late reference to epilepsy in the parish records, in Allendale in 1798, a man with "falling sickness" in the workhouse; (N) (79) PC.31/76 (unpaginated, 25 May 1798).

${ }^{66}$ Anne Digby, Madness, morality and medicine: a study of the York Retreat, 1796-1914, Cambridge University Press, 1985, pp. 135-136, 216. Doerner notes John Conolly's role in opening institutions specifically for idiots in 1847 and 1855 , Doerner, op. cit., note 64 above, p. 90 .

${ }^{67}$ (CD)EP/Whm., 20 (unpaginated, 5 August 1793);(CD)Q/S/OB, 15, p. 67. See Jones, op. cit., note 7 above for the legal framework here.

${ }^{68}$ (N)EP. 79/33 (unpaginated, 3 March 1786); EP. 79/35 (unpaginated, 21 May 1798, 28 May 1798, 17 November 1799).
} 
parishioner, Andrew Mather, was discovered to be "deranged in mind" in October 1798 , and was provided with weekly payments of two shillings (rising to two shillings and six pence) before, in March, 1799, he was transferred to the "lunatic house". Even after five months, however, there were additional costs, as the parish paid seven shillings for his wife and son to go with him to the asylum. All the signs of a conventional caution are detectable here, as the overseers initially opted for a domestic solution for several months before deciding on institutionalization. ${ }^{69}$

Institutions thus came to dominate as parishes gradually began to accept them as the best, if expensive, solution to the problem of lunatics. But this was an uneven, two-stage process. First, the evidence suggests that penal custody progressed very gradually: for example authorities in the North Riding of Yorkshire favoured domestic care for lunatics before 1700 , using the house of correction only in the eighteenth century, fifty years after County Durham and Northumberland. ${ }^{70}$ Second, the victory of the asylum was never complete, as problems of choice, for example between workhouse and asylum, continued well into the nineteenth century, long after doctors had won legal powers. ${ }^{71}$ The role of parish officers, collecting the deranged off the streets or from their desperate families, remained an enduring feature of nineteenthcentury society, and the scant documentation of this process suggests that intervention was still a last resort rather than an automatic reaction of local authorities. ${ }^{72}$ But by then the medical diagnosis and judicial supervision of the process had taken decisions out of the hands of the local officers: the community no longer dealt with its own.

\section{CONCLUSION}

Historical interpretations that attribute to the early modern period incoherent concepts and indiscriminate treatment of the mentally abnormal can no longer stand in the face of this kind of evidence. It would be wrong to say, as Mellett does, that before the eighteenth century, "there was virtually no formulated theory of insanity, nor any social strategies for dealing with the insane. Primarily, this was because the mentally-disordered presented no particular problem". ${ }^{73}$ On the contrary, both popular culture and official practice concurred with medico-legal traditions in the clear dichotomization of mental afflictions. In the context of a poor law system that could not afford wholesale solutions, there were few examples of hasty classification or harsh treatment of the victims. ${ }^{74}$ Without being too over-imaginative, one can detect a

69 (N)EP. 132/80 (unpaginated, 15 October 1798 to 28 March 1799).

70 The North Riding records are very striking: eleven of the twelve pre-1703 lunacy cases were under domestic or local restraint, while eleven of the thirteen after 1720 were in the house of correction (a break in the published sources make the immediate post-1700 period a blank). Research on the original, rather than the published, versions might clarify this pattern. See Atkinson, op. cit., note 14 above. The delays in founding a house of correction in the county are discussed in G. C. F. Forster, 'The North Riding Justices and their Sessions, 1603-1625', Northern History, 1975, 10: 117-118.

${ }^{71}$ See Walton, op. cit., note 2 above.

72 There are a few interesting mid-nineteenth-century lunacy removals from Durham City, indicating how parish officers found wandering lunatics, or collected them from their families, in (CD)EP/Du.SO., 112/9 (pieces 5, 6, 12 and 16 particularly).

${ }_{73}$ D. J. Mellett, The prerogative of asylumdom: social, cultural and administrative aspects of the institutional treatment of the insane in nineteenth-century Britain, New York and London, Garland Publishing, 1982, p. 14.

${ }^{74}$ MacDonald, op. cit., note 25 above. 
matter-of-factness in the reaction of local authorities that suggests a degree of acceptance of the possibility of mental illness and a consensus about the feasible responses. Few explanations were offered, since academic or philosophical enquiry was hardly official business, but some casual references, to physical injury or grief for example, indicate the dominance of a general theory of natural causation. ${ }^{75}$

The solutions adopted, while highly varied, nevertheless suggest a consistent balancing of welfare and social order priorities - of care as against custody. Both could be carried out in a domestic setting, since the family (or household) was both the basis of ordered society and the primary means of welfare. ${ }^{76}$ Whether the urgent need was for care or control, the family was the first resort, and only if it failed would a choice be made between domestic or institutional confinement. Since the available studies of the pre-1800 poor law suggest that enforcement of familial responsibility was a major difficulty for parishes and magistrates, the search for a wide range of alternatives, from boarding-out to institutionalization, is not surprising. ${ }^{77}$ Incarceration was consequently neither indiscriminate nor irrevocable. Decisions were not based on a would-be scientific analysis of mental conditions, nor were they random or irrational. So it is hard to agree with MacDonald that the eighteenth century in particular was a "disaster" for the insane, from which medics and reformers had to rescue its victims. This is an exaggeration, derived from a rosy view of the seventeenth and nineteenth centuries. There is more evidence of continuity throughout the period, especially if the problem is viewed from the parish level, than of abrupt transformations or radical reform. ${ }^{78}$

As for the victims themselves, they are still obstinately silent, for these sources record only the attitudes and responses to them of family, community, and official bodies. The fate of the poor is all too often to be defined by those to whom they are a problem-and those studied here were often among the poorest of the poor. Thus we have a reasonably clear picture of the relationships of the mentally disabled with their caretakers, professional and amateur, which might otherwise be unknown. ${ }^{79}$ Also, the changing context, medical and institutional, becomes more apparent when the county framework of the local community is studied comparatively over such a long period. The widening of the local horizons and the hardening of external influences on parish decisions are crucial features of the latter part of the early modern period. At the local level, therefore, we can see factors that shaped the social experiences of the mentally disabled within their personal and official relationships, but we still lack, perhaps inevitably, a history of their private world.

\footnotetext{
${ }^{75}$ See the reference to grief in DR.V, 2, f.123 (1565-75), in the consistory court of Durham (Department of Palaeography and Diplomatic, Durham)- "Janet her dame hath not had her wits perfectly since the death of her husband Jarred". Supernatural theories seem to have flourished longer in America, to judge from Mary Ann Jimenez, 'Madness in early American history: insanity in Massachusetts from 1700 to 1830', J. soc. Hist., 1986, 20: 25-44.

${ }^{76}$ See P. Rushton, 'Property, power and family networks: the problem of disputed marriage in early modern England', J. Fam. Hist., 1986, 11: 205-219.

$77 \mathrm{~J}$. W. Ely, 'The eighteenth-century poor laws in the West Riding of Yorkshire', Am. J. legal. Hist., 1986, 30: $1-24$.

${ }_{78}$ Macdonald, op. cit., note 8 above, pp. 230-231.

${ }^{79}$ Neugebauer, op. cit., note 10 above, p. 167 , for criticism of the over-reliance on printed sources as a guide to relationships between patients, doctors, and the wider society.
} 